\title{
REINTERPRETATION OF ETHIC VALUE IN MINANGKABAU'S SUPERSTITION
}

\author{
Ridha Hasnul Ulya \\ SMPN 7 Kubung, Kab.Solok \\ E-mail: ridha_hasnul.ulya@yahoo.com
}

Submit: 07-12-2017 Review: 24-02-2018 Accepted: 10-03-2018

DOI: https://doi.org/10.22202/tus.2018.v4i1.2389

\begin{abstract}
This article aims to reveal reinterpretation ethic value of Minangkabau's superstition especially in the society of Kubuang Tigo Baleh's superstition. Besides the concepts of superstition, superstition in well-mannered culture and superstition pattern of the society of Kubuang Tigo Baleh are explained. There are four patterns of superstition, namely negative, positive, prediction and witchcraft pattern. However, in the process of pattern meaning the lofty ethic values are framed and considered as local wisdom of the society in Kubuang Tigo Baleh which is appropriate, well-mannered, educated and existence acknowledged as a belief.
\end{abstract}

Keywords: Ethic value, Minangkabau's society, Reinterpretation, Superstition

\section{INTRODUCTION}

Superstition is always being a part of culture in society. Eventhough the superstition always holded out in wrong way, however it makes the culture in society last longer from generation to generation. Superstition is something that rarely found in society. Thus, superstition that is based on any reason or knowledge is already exist since the era of great-grandparents. Eventhough some beliefs are disappear by the time, however new beliefs begin to appear. For example, many newspaper and magazine have horoscope section weekly.

Superstition that is still exist nowadays influence human attitude. Survey that was done by Torgler (2003:2) shows that astrology gives powerful impact in recent decades. Another survey also shows the improvement of people's belief and interest toward superstition (Wiseman and Watt, 2004:292). Therefore, it indicates that superstition is the topic that gets much attention and tendency to be researched.

Relevant research was done by Yunzhou (2012) about the relationship of superstition information toward tourists' interest to visit tourism object. The result of the research shows that there is positive relationship between tourist's attitudes, 
for them who have belief toward superstition, with their preference to visit the tourism object. Besides, $7 \%$ of the respondent stated that they interest to visit the tourism object that has superstition interest in past 12 months. Thus, it can be concluded that more positive the tourist act toward superstition, the happier them visit the place.

Minangkabau is one of the ethnic group that has unique local wisdom in Indonesia. Other ethnics such as Papua, Kalimantan and Bali have tangible local wisdom (architechture, natural resources conservation), Minangkabau has intangible local wisdom that is language. Minangkabau has known as the ethnic which people produce written work in form of manuscript. It proves Minangkabau is well known with its local wisdom in language. It pushes Minangkabau people to use language carefully.

The uniqueness, that can be seen in the habit of Minangkabau people, especially in Kubuang Tigo Baleh society, is the using of superstition. Kubuang Tigo Baleh society is still use superstition in their daily life. The society believes that superstition can avoid them from danger. Superstition in Kubuang Tigo Baleh society purposed for well-mannered norm. For example, Jan mambae di hari sanjo, beko kanai anak dubilih (It is forbidden to throw away something at dusk, it will hit the devil). This superstition purposed to forbid person from throwing out something at dusk in order to avoid him/ her disturbing people who want to do Maghrib pray and rest. This purpose gives us wise lesson about well-mannered norm to create ethic education to avoid the violation.

In social life, there is a control to manage the members of society in order to make their attitude still in norm. It means, human attitude is always bordered by norm. This border is in form of suggestion and prohibition. This suggestion and prohibition is called ethic value. In society, there are rules and prohibition for all members of society based on the norm and social values. Norm and social values take part as the guidance of better attitude for the members of society to avoid social deviation.

In previous time, Kubuang Tigo Baleh society lives in wiser thought than nowadays. For example, in keeping healthy body, Kubuang Tigo Baleh society 
rarely gets sick. People at that time think that the hospital and medical staff were limited so that they thought that they have to keep healthy. Moreover, it can be understood that Kubuang Tigo Baleh society life by planting crops and farming and at night they go to mosque on foot. This condition make the society did physical activity mostly.

Food that we eat is changed into the energy that can be used to do the activities (farming, praying, practicing self-defence art) so that the society is still in good shape. On the contrary, Kubuang Tigo Baleh society nowadays lives in different way of life. The society is rarely do physical activities. Most of them work in the office, do the pray at the office and home and it makes them do not move much. This condition leads the society life unhealthy: for example do not do another activity after having dinner and directly go to bed, it can cause bloated stomach. It is similar with the superstition "we cannot sleep after eat, it can cause bloated stomach". Thus, it is important for the member of society especially children and teenager to know what are the moral values that needed to be done and avoided. In other words, if the society maximalizes the function of superstition as the tools to educate childrens' ethic, the society tend to life in the right way. Based on the problems above, it is important to discuss about the pattern of superstition in Kubuang Tigo Baleh society.

\section{B. Discussion: Reinterpretation of Minangkabau's Superstition}

\section{Basic Understanding of Superstition}

Folklore can be categorized in several ways based on the certain characteristics and on how they expressed. Three main categories that mostly used to describe folklore is verbal, material, and customary (Sims \& Stephens (2011). Danandjaja (1991) categorizes folklore into three, oral folklore, partly oral folklore and non-oral folklore. One of the parts of partly-oral folklore is superstition. The term of superstition comes from word superstition or superstitious. Superstition derived from the words super or supernatural and state which means statement. In other words, superstition has meaning the statement that contains the supernatural or unusual information. 
Experts have stated that superstition is the culture phenomena and relativity long time ago. Realtivity in superstition illustrated by Ulya (2018) as "The thing that is believed by one person but not by other people; not believed by a person in one time but believed in another time. Ulya (2017) explains that superstition is not related with intelligency, living in a city or a village, and religion. He also states that young people believes easily to superstition than old people.

Superstition appears for the first time to explain the nature and existence of human being, in keeping their loyalty and luck in order to avoid bad things that are not understood by them, and to predict the future. Superstition is the belief that is not based on the facts or events that can be proved (Omobola, 2013:222). For example, some people believes if black cat passed across the road, it wil bring unluck. The reason is they do not have any beliefs about that and cannot prove the unluck.

Superstition represents and basis human fear that is caused by indefinite things in world. In other words, superstition is the sign of acceptance toward irresponsive and limitation of human ability. Moreover, superstition is the sign of universe acceptance, which the process scheme is still beyond human understanding (Omobola, 2013:223). The term of superstition refers to the belief or influence that cannot be suited with rational thought. Superstition is irrational belief where object, action or purpose is linked with the events that influences the caused result.

Superstition relates with beliefs formed by irresponsive act and unknown fear. Most of the superstition refers to the deviation interpretation toward nature incident (Omobola, 2013:223). Superstition can be called as the acts that do not have irrational basic or history. Mostly, this belief is already known long time ago and inherited from generation to generation. Superstition is easily formed and has personal feature. For example, a student writes literary work using certain pen and since that day, the pen brings luck to him/ her; a horse rider can be influenced easily for example the black horse will bring luck to him. (Omobola, 2013:224). So that, superstition can be classified into three form religion, culture and 
personal. Superstition has been so long interest the researchers and it is linked to some factors. For example, belief is mostly found by women, people with low intelligence and low economy (Ulya, 2016). Another factor that is found is related with the level of belief including emotional disability, low cognitive ability and the tendency of irrational beliefs.

Religious orientation related with superstition consists of three categories, fundamental, moderat and liberal. (MacDonald, 1995:366). Moreover, religious orientation refers to religious practice frequency and the power of religion belief. Religion is related with superstition and beliefs about paranormal and found in several researches. MacDonald (1995:366) found that high level of religion is related with belief and paranormal experience for example telepathy. Beck dan Miller (2001:277) also found that the relationship between high religion and supernatural. The participants have high believe of religion and also negative emotional experience. The finding showed that there is a correlation between religion belief and superstition.

Based on the explanation above, it can be understood that there is a thin line that differentiate the concept of superstition with religion belief. A fully accepted thing as pure religion statement is seen as weak superstition fro them who have different religious belief.

\section{Reinterpretation Minangkabau's Society Superstition Viewed from the Pattern}

One of the customaries in Kubuang Tigo Baleh society is local wisdom in well-mannered norms. This norm is called as sumbang duo baleh (twelve nonethic). According to Ibrahim (2009:156), sumbang is the attitude and behavior that is not appropriate with tradition ethic. Minangkabau tradition has 12 sumbang, they are (1) sumbang duduk (sit), (2) sumbang berdiri (stand), (3) sumbang diam (silent), (4) sumbang berjalan (walk), (5) sumbang kata (talk), (6) sumbang melihat (see), (7) sumbang berpakaian (dressed), (8) sumbang bergaul (socialize), (9) sumbang bekerja (work), (10) sumbang tanya (questioning), (11) sumbang jawab (answering), dan (12) sumbang kurenah (behavior) (Ibrahim, 2009:156). 
This twelve sumbang are the basic of superstition. Superstition is told when a child or society act bad or out of the norm in tradition. If a child do bad thing (if sumbang happen), parent will use superstition as the tool to give deterrent effect to the child. Besides, local wisdom value in superstition contain of how a person should behave in some matters such as sit, stand, walk, work, etc. So that, sumbang duo baleh is the basis for the speaker in expressing superstition. Based on this statement, the analysis of the patterns of Minangkabau Society Superstition in Kubuang Tigo Baleh needed to be done by comparing the types of superstition as follow:

\section{a. First Pattern: Negative superstition}

The most discussing theme about superstition is unluck. In other words, the expression of unluck can be called as negative superstition. England people has belief that if an apple eaten without washing it first, it will invite bad spirit to the person who eat the apple (Potter, 1990). The example of first pattern of superstition in Kubuang Tigo Baleh is "Indak buliah mamintak barang yang alah wak agiahan ka urang beko panjang lidah awak beko." (we can not taking back the thing that already given to other people, if not the tongue will be long).

From the example above, there is basic similarity between western and Kubuang Tigo Baleh superstition if seen from first pattern of negative superstition. In western superstition, it can be understood that before eating an apple, it needs to be washed first, if not bad spirit will come. Similarly, the superstition in Kubuang Tigo Baleh has meaning that we can not taking back the thing that already given to other people, if not the tongue will be long. Both of these examples functioned as media or tool to educate someone in behave. When someone wants to eat an apple, the apple should be washed to avoid germs. This is also happen in Minangkabau; someone is not allowed to be stingy. So that, the second function of superstition is to educate someone's ethic in behave.

\section{b. Second Pattern: Positive Superstition}

Another general theme in superstition is related with luck. This category is contrast with the first pattern, the belief of someone eating the whole part of apple (including the core) will get luck (Opie \& Tatem, 1989). The explanation about 
luck here is vary in one superstition with others. The example of second pattern in Kubuang Tigo Baleh society is "Indak buliah makan basiso beko managih nasi tu beko." (it is not allowed to leave the leftover food, the food will cry).

From the example above, there is basic similarity between western superstition with Kubuang Tigo Baleh superstition seen from positive superstition pattern. In the example of western superstition it can be understood that we should not leave the leftover food because it will throw away luck. So that, the parents give the superstition in order to be done by the children.

This is similar with the superstition in Kubuang Tigo Baleh society. The society beliefs that if a child leaves the food, the food will cry. An interesting part of this superstition is the effect caused; there is irrational thought happen, when people leave the leftover food. It shows that Kubuang Tigo Baleh society belief this as great sumbang and it is not ethic if we leftover the food. The parents use this superstition to make the children do not waste their food.

\section{c. Third Pattern: Prediction Superstition}

Superstition is also related with prediction. For example, apple is strongly related with love in western. Most of the superstition that is related with apple is also can give prediction. If a young woman wants to know the identity of her partner in the future, she has to throw away the skin of the apple through her left shoulder, then the skin will form the initial of the partner's name (Opie \& Tatem, 1989). It needed to be highlight that prediction superstition in essential is donr to know more rather than change the future. The example of third pattern of superstition is : "Indak buliah maalau kupu-kupu naiak ka ateh rumah sabab itu tando ado urang jauah datang ka rumah." (it is not allowed to chase away the butterfly inside the house, the butterfly is the sign of guests will come to the house)

From the example above, there is a basic different between western superstition and Kubuang Tigo Baleh from prediction pattern. In western superstition, it can be understood that there is only magical information, the prediction of initial name of the partner's name. Besides, superstition in 
Kubuang Tigo Baleh there is two things in the statement. First, there is a magical that butterfly inside the house is the sign of guest that will come, the second meaning is we are not allowed to disturb the butterfly in the house. This means that Kubuang Tigo Baleh society prohibited people especially children to kill animals which is based on their religion belief.

\section{d. Fourth Pattern: Magic Superstition}

Other superstition group related with the ritual done to change the future based on what is wanted. This ritual involves the use of traditional charm, curse, spell to change the future. For example, the superstition "an aplle a day keeps the doctor away" or wart can be healed by dividing an apple into two and rub the apple to the wart then the apple should be burried (Ulya, 2017). The example of the fourth pattern in Kubuang Tigo Baleh society is "Jikok mambangun rumah jan lupo malumuan darah ayam ka tiok tiang bia rumah indak tabaka beko." (if we build the house, do not forget to smear the chicken blood to the pole in order to avoid the house to be burnt).

Based on the example above, it can be understood that there is a fourth pattern of superstition in Kubuang Tigo Baleh society. in western superstition it is stated that an apple is believed can avoid someone from diseases. It is purposes to make people consume apple since the apple contains of many vitamins and minerals to keep the body healthy. Another incidential factor is to make the people or children want to eat fruit. So that, this superstition is appeared to maintain healthy body.

Similarly, Kubuang Tigo Baleh society also has fourth pattern of superstition. The example above shows that chicken blood can be used as the preventive of burnt house. If this superstition is understood in wrong way it will cause multi negative interpretation. The superstition is incidential and appears because one of the worker wants the landlady slaughtered the chicken for the feast. This is considered as sumbang since Minangkabau's society usually do such a ceremony for the happy events such as harvest, building the house, batagak penghulu, or akekah. 


\section{Reinterpretation Minangkabau's Society Superstition Viewed from the Well-Mannered Culture Framework}

Culture is related with well-mannered or appropriateness. Only wellmannered that is considered culturally meanwhile non well-mannered is considered as non cultural. Non well-mannered is happen because of the accident, misunderstanding, or self-desire. In a certain relationship, an unusual wellmannered, a child-parents, wife-husband, or friend-friend can be estimated as the effort to do manipulation (Blum-Kulka, 1992:276). The relationship of non-well mannered and deception are never been explained and linked to cultural norms. These norms are just tell the people about bad attitude. It seems like the people themselves should know which is bad attitude, and it is not the function of culture to give this information to them.

Norms are the factors that can give explanation about human attitude. The norms are cultivated in their thought and people rely on it in order to understand how others behave and give them the example of how to behave. Based on this explanation, it can be said that norms is the foundation of social interaction itself as the combination of social community. Norm is only tell about well-mannered. Moreover, well-mannered is the only thing in culture and non well mannered is shoved aside to the phenomenon outside the culture.

Social norms is always show people how to act in well-mannered. Culture become the "positive" and "good" entity where people respect each other and friendly. In other words, culture is a good place to life and delightful for the members. The relationship between culture and good behavior is clearly seen in some examples. Ide states that "people raised in good way mostly obey the norms"(Ide, 1982:377). Similarly, Lakoff (1975:69) states that "in collective thought, culture implicitly has the concept about how human should behave: a target that should be reached by the members and to judge themselves". Most of us, in some condition, is too respectful (impossible) to break the norms so that we know the difficulties and risk that we faced (Lakoff, 1975:89). So that, qualitative aspect of norms with conceptual bias toward well-mannered act and the relationship of well-mannered system with culture level are function more to 
improve the definition of culture in positive way. The culture is about well care, well maintenance, and well human being in general. Culture is not only a qualitative entity, but also the entity that is "right in ethic".

Superstition is a part of folklore. It can be linked with the theory about well-mannered acts. Superstition contains of ethic or how we behave in social life. In other words, there is well-mannered contents in superstition because it is a part of culture. For example, in Kubuang Tigo Baleh society, there is a superstition "it is prohibited to whistle at night because it can invite the snake inside the house". This superstition is the form of interpretation of norms or well-mannered norms. The message in this superstition is how we should behave based on the ethic in the society. If someone whistle, it can make sound that can disturb other people who want to take a rest. So that, superstition can be used as the alternative of wellmannered to overcome the problems of society ethic. So that, the society will not move out of the norms in the culture.

\section{CONCLUSION}

The characteristic of Minangkabau's society is local wisdom arranged in well-mannered norms. The norm is called as sumbang duo baleh. The twelve sumbang is the basic of superstition appearance. Superstition is told to a child or people who act out of the norms in custom. Parents use superstition as the tools to educate childrens' ethic and to give deterrent effect. Besides, there are four paterns of Kubuang Tigo Baleh society namely yaitu positive, negative, prediction, and magic pattern of superstition in ethic value border. In short, it is important to do reinterpretation ethic value of Minangkabau's superstition.

\section{REFERENCES}

Beck, R., \& Miller, J. P. (2001). Erosion of belief and disbelief: Effects of religiosity and negative affect on beliefs in the paranormal and supernatural. The Journal of Social Psychology, 141, 277-287.

Blum-Kulka, S. 1992. The Metapragmatis of Politeness in Israeli Society, inRichards Watts, Sachico Ide, K. Watts (eds). Politeness in Language:Studies in Its History, Theory and Methods. Boston: Allyn and Bacon, Inc. 
Danandjaja, James. 1991. Folklor Indonesia: Ilmu Gosip, Dongeng, dan lain-lain. Jakarta: Pustaka Utama Grafiti.

Ibrahim Dt. Sanggoeno Diradjo. 2009. Tambo Alam Minangkabau. Bukittinggi: Kristal Multimedia.

Ide, Sachiko. 1982. Japanese Sociolinguistics Politeness And Women's Language. Lingua 57. 357-385. North Holand Publishing Company.

Lakoff, Robin. 1975. Language and Woman's and place. New York: Harper and Row.

MacDonald, W. L. (1995). The effects of religiosity and structural strain on reported paranormal experiences [Electronic Version]. Journal for the Scientific Study of Religion, 34, 366.

Omobola, O.C (2013). An Overview of Taboo and Superstition among the Yoruba of Southwest of Nigeria. Mediteranean Journal of Social Sciences. Vol 4 No.2 pp. 221-226.

Opie, I., \& Tatem, M. (Eds.) (1989). A Dictionary of Superstitions. Oxford: Oxford University Press.

Potter, C. (1993). A-Z of Superstitions. London: Chancellor Press.

Sims, M. C., \& Stephens, M. (2011). Living Folklor, An Introduction to the Study of People and Their Traditions. Utah: Utah State University Press.

Torgler, B. 2003. "Tax Morale: Theory and Analysis of Tax Compliance.” Dissertation. Switzerland. University of Zurich.

Ulya, Ridha Hasnul. (2016). Aksiologis Sastra dalam Gamitan Nilai Etika pada Superstisi Masyarakat Kubuang Tigo Baleh. ASEAN Comparative Education Research Network Conference (ACER-N) Proceeding, Halaman 1223-1233.

Ulya, Ridha Hasnul. (2017). Mustika Adab Masyarakat Kubuang Tigo Baleh dalam Bingkai Superstisi dan Sumbang Duo Baleh. International Seminar on Education, Language, Literature, and Art (ISELLA) Proceeding, Universitas Islam Riau, Halaman 476-490.

Ulya, R.H., Thahar, H.E., Asri, Y., \& Agustina, A. (2018). Cultural manifestation in superstition of Minangkabau society. Education, Social Sciences and Technology Application in Digital Era (pp. 422-429). Padang: Fakultas Ilmu Pendidikan. https://doi.org/10.29210/2018160.

Wiseman, R \& Watt, C. 2004. "Measuring Superstitious Belief: Why Lucky Charms Matter" Personality and Individual Differences, Volume 37, Nomor 8, Hal. 15331541.

Yunzhou Zhang. (2012). The Effects of Superstition as Destination Attractiveness on Behavioral Intention. Artikel. Amerika: Virginia Polytechnic Institute. 
